\title{
40 \\ KESENJANGAN PENDIDIKAN DESA DAN KOTA
}

\author{
Oleh: \\ Benediktus Vito, Hetty Krisnani, \& Risna Resnawaty \\ Email: \\ (vitobenediktus@yahoo.co.id; hettykrisnani@yahoo.com; happytruz@yahoo.com)
}

\begin{abstract}
ABSTRAK
Setiap warga negara berhak memperoleh pendidikan dikarenakan memperoleh pendidikan merupakan hak dari warga negara. Begitu juga untuk masyarakat yang ada di perkotaan dan pedesaan, mereka semua berhak menerima pendidikan yang layak. Namun kenyataannya masih banyak kasus kesenjangan pendidikan yang terjadi di perkotaan dan di pedesaan. Hal ini dapat terlihat dari jumlah tenaga pengajar yang terdapat di sekolah perkotaan dan sekolah di pedesaan. Jumlah guru lebih banyak terdapat di perkotaan dibandingkan dengan dipedesaan. Rendahnya minat guru mengajar di pedesaan diakibatkan oleh minimnya akses transportasi serta fasilitas sekolah yang buruk yang terdapat di pedesaan. Selain itu kesenjangan pendidikan antara perkotaan dan pedesaan dapat terlihat dari sekolah- sekolah di perkotaan yang mempunyai fasilitas baik pastinya juga memiliki pengajar yang berkompeten sehingga nantinya menghasilkan siswa- siswa yang cerdas. Hal ini berbanding terbalik terhadap sekolah- sekolah yang terdapat di pedesaan yang mempunyai fasilitas sekolah yang kurang baik dan tenaga pengajar yang kurang kompeten. Pemerintah dengan segala upayanya khususnya Kementrian Pendidikan dan Kebudayaan Republik Indonesia dalam hal ini sedang berupaya untuk mengatasi kesenjangan pendidikan yang terjadi di pedesaan dan perkotaan yaitu dengan mengeluarkan Program Sarjana Mendidik di Daerah(SM3T) yang bertujuan untuk mengatasi masalah kesenjangan pendidikan antara desa dan kota. Tentunya pekerja sosial bisa membantu mengontrol hasil dan ikut berperan dalam pelaksanaan kebijakan.
\end{abstract}

Kata kunci: Pendidikan, pekerja sosial, kesenjangan pendidikan desa dan kota.

\section{Pendahuluan}

Sebagai Negara yang besar dan dengan sumber daya alamnya yang melimpah pada dasarnya Indonesia memiliki potensi yang besar untuk menjadi salah satu Bangsa yang maju, bermartabat dan lebih baik dari saat ini, dan itu semua dapat terwujud tentunya dengan dukungan sumber daya manusia yang berkualitas, kreatif dan memiliki visi yang jelas dan terarah untuk kemajuan Bangsa. Untuk memenuhi tujuan terciptanya sumber daya manusia yang berkualitas tentunya pendidikan adalah faktor terpenting yang tidak dapat dipisahkan.

Tujuan dari pendidikan nasional tidak saja hanya mencetak sumber daya manusia yang cerdas akan tetapi juga mampu mencetak kepribadian yang berkarakter, berakhlak, kreatif, memiliki misi visi dan bertanggung jawab serta sebagai warga negara yang baik. Kesuksesan seseorang tidak pernah lepas dari potensi yang dimiliki oleh orang tersebut, potensi dalam arti tidak saja berbicara tentang skill akan tetapi meliputi kemampuan seseorang mengimplementasikan potensi yang dimiliki untuk orang banyak, kemampuan mengelola diri dan orang lain. 
Pekerjaan sosial merupakan suatu profesi yang professional yang mempunyai banyak kajian fokus, salah satu fokusnya yaitu menangani masalah- masalah yang ada di sekolah atau lebih dikenal dengan pekerja sosial sekolah walaupun pada kenyataannya masih banyak sekolah yang tidak memiliki pekerja sosial. Selain menjadi pekerja sosial sekolah, peran pekerja sosial juga dapat menjadi mengontrol dan ikut berperan dalam pelaksanaan kebijakan (controlling and communicator).

\section{Kesenjangan Pendidikan Desa dan Kota}

Pendidikan adalah kunci kemajuan suatu bangsa dan menjadi isu yang selalu menarik untuk dikaji. Pendidikan nasional tak henti-hentinya menuai banyak permasalahan. Pengertian pendidikan menurut Undang Undang SISDIKNAS no. 20 tahun 2003, adalah sebagai usaha sadar dan terencana untuk mewujudkan suasana belajar dan proses pembelajaran sedemikian rupa supaya peserta didik dapat mengembangkan potensi dirinya secara aktif supaya memiliki pengendalian diri, kecerdasan, keterampilan dalam bermasyarakat, kekuatan spiritual keagamaan, kepribadian serta akhlak mulia. Kamus Besar Bahasa Indonesia menjelaskan bahwa pendidikan berasal dari kata "didik" dan mendapat imbuhan berupa awalan 'pe' dan akhiran 'an' yang berarti proses atau cara perbuatan mendidik. Maka definisi pendidikan menurut bahasa yakni perubahan tata laku dan sikap seseorang atau sekelompok orang dalam usahanya mendewasakan manusia lewat pelatihan dan pengajaran.

Mengacu pada definisi pendidikan diatas, yaitu pendidikan sebagai proses pembelajaran supaya peserta didik dapat mengembangkan potensi dirinya secara aktif. Begitu juga dengan masyarakat yang ada di desa. Masyarakat desa juga memiliki peluang yang sama dengan masyarakat kota untuk memperoleh pendidikan. Pemerintah membuka peluang pendidikan yang sama untuk masyarakat desa maupun kota. Bahkan, semangat juang masyarakat desa lebih tinggi daripada masyarakat kota. Karena masyarakat kota beranggapan bahwa pendidikan di desa tidak begitu maju karena kekurangannya sarana dan prasarana yang memadai. Karena pendidikan di desa dengan dikota berbeda jauh.

Berikut beberapa contoh timpangnya pendidikan antara pendidikan di desa dan di kota. Dikutip dari kompas.com mengenai murid SD Negeri Cicaringin 3, Kecamatan Gunung Kencana, Lebak, Banten yang harus meniti kabel baja menyeberang Sungai Ciliman saat pulang dari sekolah. Lambannya pemerintah membangun infrastruktur membuat mereka harus rela berjalan sejauh 6 kilometer pergi dan pulang untuk mencapai sekolah dan berisiko terjatuh ke sungai. Bahkan berita ini sempat terdokumentasikan oleh majalah dailymail, yang bertuliskan Think the school run is bad? Children face Indiana Jones-style river crossing every day after floods cut off their community. Hal ini telah mencoreng wajah pendidikan Indonesia di tingkat dunia, dan tentunya contoh kasus ini memalukan nama Indonesia di tingkat dunia, berita ini sempat menjadi trending topic saat itu.

Sebuah jembatan di Kampung Sungai Tanuak Kenagarian Barung Barung Belantai Tengah Kecamatan Koto XI Tarusan Kabupaten Pesisir Selatan, Padang. Putus sejak 25 November dan sampai saat ini masih belum diperbaiki, putusnya jembatan membuat anak-anak di kampung itu yang bersekolah di SDN nomor 42 Talawi terpaksa harus turun menyeberangi sungai untuk mencapai sekolah mereka.(http://www.padangmedia.com/1-Berita/89949-Jembatan-Putus--Anak-SekolahHarus-Menyeberang-Sungai.html)

Setelah kasus jembatan miring di Lebak, Banten dan kasus di Kabupaten Pesisir Selatan, Padang. Kasus Jembatan miring juga ada di Desa Kangenan, Pamekasan, Jatim. Di jembatan inilah, warga yang akan pergi kerja atau sekolah, mempertaruhkan nyawa termasuk para pelajar terpaksa harus melintas jembatan tersebut karena merupakan akses terdekat ke tempat tujuan. (http://foto.detik.com/readfoto/2012/03/26/143618/1876475/157/2/kembali-nyawa-anak-sddipertaruhkan-di-jembatan).

Susahnya akses menuju sekolah, tidak membuat patah semangat anak anak yang berada di pedesaan untuk bersekolah dan mendapatkan pendidikan meski mereka harus bersusah payah dan menghadapi rintangan yang begitu berat untuk mencapai tujuan mereka, yaitu belajar disekolah untuk 
mencapai cita-cita. Hal ini berbanding terbalik dengan pendidikan yang berada di perkotaan, yang dimana akses menuju sekolah sangatlah mudah dan banyak alat transportasi yang memudahkan anak anak yang bersekolah untuk sampai ditujuannya dalam waktu yang singkat.

Kesenjangan pendidikan yang terdapat di pedesaan dan perkotaan tidak hanya dalam akses menuju sekolahnya saja, tetapi masih banyak aspek- aspek kesenjangan pendidikan yang lainnya, aspek yang lainnya adalah kesenjangan sarana dan prasarana sekolah yang terdapat di pedesaan dengan sekolah yang terdapat diperkotaan. Dikutip dari Liputan 6 Pagi SCTV, memberitakan kondisi memprihatinkan Madrasah Ibtidaiyah (SD) Darul Ulum di pesisir pantai Desa Mawu, Kecamatan Ambalawi, Kabupaten Bima. Sekolah yang berdiri sejak 2007 hanya memiliki fisik bangunan semi permanen. Berdinding anyaman bambu dan berlantai tanah. Tanpa bantuan pemerintah, pendiri sekolah dan para guru tetap tegar hingga kini. Bisa dibayangkan, seperti apa kondisi waktu belajar setiap hari. Di sisi lain, guru pun seakan hanya berbekal idealisme mereka sebagai pengajar, tanpa imbalan yang memadai sebagai pemberi ilmu bagi masa depan muridnya. (http://news.liputan6.com/read/2044900/potret-pendidikan-daerah-terpencil)

Ditempat berbeda namun masih menyorot tentang buruknya sarana dan prasarana pendidikan yang terdapat di pedesaan. Terdapat Sebuah gubuk nyaris rubuh berdiri di Desa Bukit Subur, Kecamatan Tabir Hilir, Merangin, Jambi. Orang desa sana menyebutnya sekolahan. Gubuk itu dibangun murni oleh warga setempat, tiga tahun silam, untuk tempat anak-anak mereka belajar. Bangunan tersebut memang sekolahan. Sekolah Dasar Negeri (SDN) 29 Kelas Jauh namanya. Sekolah ini sangat jauh dari layak untuk disebut sebuah sekolahan. Kelas belajarnya hanya ada dua ruangan. Berbeda sekali dengan sekolah kebanyakan. Ironisnya, bangunan kelas jauh SDN 29 ini hanya terbuat dari kayu dan beberapa barang bekas. Dindingnya terbuat dari papan. Tiangnya dari kayu balok bulat tanpa disuguh halus. Atapnya hanya memakai seng-seng bekas, yang jika hujan datang pasti bocor. (http://infojambi.com/topik-utama/8306-potret-dunia-pendidikan-merangin-adasekolah-mirip-kandang-kambing.html)

Tentu hal ini sangat kontras dengan sekolah yang terdapat di perkotaan. Sekolah dengan bangunan yang nyaman dan aman untuk ditempati. Fasilitas yang sangat memadai, seperti ruangan komputer, sarana olahraga, ruangan puskesmas dan kantin maka akan membuat suasana belajar akan sangat nyaman bagi siswa- siswa yang bersekolah di perkotaan. Jika dibandingkan dari contoh kasus diatas terkait dengan sarana dan prasana pendidikan pedesaan dan perkotaan tentu akan terlihat sekali kesenjangan pendidikan yang terjadi.

Aspek kesenjangan pendidikan yang terakhir adalah sumber tenaga pengajar atau guru yang terdapat di sekolah pedesaan dan perkotaan. Guru di kota jauh lebih banyak dibandingkan guru di desa. Hal ini dapat terlihat dari contoh kasus berikut ini. Sejumlah mahasiswa dari berbagai perguruan tinggi di Makassar, berunjukrasa memperingati Hari Pendidikan Nasional di Tol Reformasi, Makassar, Sulsel, Kamis (2/5/14). Sejumlah mahasiswa yang berunjukrasa meminta pemerintah lebih serius dalam menangani jumlah guru yang menurut mereka hampir 80 persen jumlah guru tersebar dikota dan 20 persen sisanya tersebar di desa. Jika hal ini terus dibiarkan, maka kualitas pendidikan di Indonesia akan sangat timpang karena hanya penduduk kota saja yang mempunyai kualitas SDM handal, sedangkan penduduk desa akan terus terbelakang. (http://www.beritasatu.com/pendidikan/123153-kesenjangan-guru-di-kota-dan-desa-masihtinggi.html)

Sementara di perkotaan jumlah tenaga pengajar sangatlah memadai bahkan melebihi kapasitas, bahkan ada satu mata pelajaran yang memiliki dua guru. mendapatkan pendidikan adalah hak setiap warga negara karena dengan memperoleh pendidikan, otomatis setiap warga negara akan mendapatkan pekerjaan. Dengan pekerjaan, masyarakat bisa produktif untuk memenuhi kebutuhan hidup. Sumber Daya Manusia (SDM) yang berkualitas tentu akan berdampak pada perekonomian, saat ini hanya penduduk di kota besar seperti Jakarta dan kota besar lainnya yang mempunyai kualitas pendidikan yang bagus sementara kualitas pendidikan di desa masih sangat buruk. salah satu 
penyebab rendahnya minat mengajar guru di desa adalah minimnya akses transportasi serta fasilitas komunikasi yang buruk. Permasalahan tersebut bisa diatasi dengan memberikan upah yang lebih besar kepada guru yang mau mengajar di daerah terpencil daripada upah guru yang mengajar di kota. jika porsi guru di desa dan di kota sudah seimbang, maka kualitas pendidikan di Indonesia semakin baik karena semua penduduk mendapatkan pendidikan.

\section{Kesimpulan}

Kesenjangan Pendidikan pedesaan dan perkotaan dapat diatasi dengan langkah- langkah berikut, pemerintah dalam hal ini menjadi perhatian yang khusus. Tugas pemerintah disini tidaklah mudah, mulai dari merehabilitasi bangunan sekolah yang sudah tidak layak guna yang terdapat dipedesaan. Ataupun membangun ruangan-ruangan yang juga mendukung kegiatan belajar megajar seperti laboratorium dan perpustakaan sekolah yang terdapat di pedesaan. Pemerintah juga harus melakukan kerjasama dengan berbagai pihak terkait untuk memaksimalkan anggaran APBN untuk pendidikan dan untuk meningkatkan kualitas pendidikan.

Faktor terpenting dalam mengatasi permasalahan kesenjangan pendidikan yang terdapat di pedesaan dan perkotaan adalah guru. Guru adalah orang yang memilki tugas dan tanggung jawab dalam mencerdaskan anak bangsa untuk mewujudkan pendidikan yang bermutu. Meskipun dalam mewujudkan pendidikan yang bermutu tidaklah hanya faktor tenaga pendidik yang harus diperhatikan tetapi juga masalah alokasi dana, sarana dan prasarana yang juga mendukung. Namun, guru tetaplah yang memiliki peranan besar dalam memajukan dunia pendidikan. Pemerintah pusat maupun pemerintah daerah harus menyebarkan guru-guru berkualitas ke desa-desa agar kualitas pendidikan di pedesaan bisa mengimbangi pendidikan di perkotaan untuk mendukung rencana tersebut maka pemerintah bisa menyiapkan insentif yang lebih besar bagi guru berprestasi yang mau mengajar di desa.

Pendidikan seharusnya menjadi skala prioritas bagi agenda pembangunan pemerintah daerah. Melalui percepatan pembangunan pendidikan yang menyentuh segala aspek dan dinamika pendidikan diharapkan akan mampu mengangkat kualitas pendidikan di daerah. Pembangunan pendidikan di daerah harus bersifat adil, partisipatif dan terintegrasi, sehingga kesenjangan mutu yang ada saat ini dapat diatasi dalam waktu yang tidak terlalu lama. Berbagai kebijakan dan program kerja yang telah dan sedang diluncurkan pemerintah daerah maupun pemerintah pusat, semuanya itu tujuannya hanya pada upaya pencapaian tingkat kualitas pendidikan. Walaupun di satu sisi, untuk mengatasi ketertinggalan mutu pendidikan suatu daerah menjadi tanggung jawab pemerintah daerah itu sendiri, namun pemerintah pusat lebih berperan untuk melakukan fasilitasi dan koordinasi.

Pemerintah juga sudah mengeluarkan solusi dalam mengatasi keterbatasan guru di pedesaan yaitu dengan program SM3T (Sarjana Mendidik di Daerah Terdepan, Terluar, dan Tertinggal) merupakan salah satu bentuk intervensi pemerintah dalam rangka mengatasi kesenjangan pendidikan di Indonesia. SM3T telah mengirimkan lebih dari 10.000 sarjana pendidikan terbaik dari seluruh Indonesia baik yang berasal dari PTN maupun PTS. SM3T ini sudah berjalan dari tahun 2012. Sarjana- sarjana yang baru lulus ini akan ditempatkan di pelosok daerah dan mengabdi menjadi pengajar selama satu tahun disana. Setelah mengabdi selama satu tahun di daerah mereka kemudian mengikuti pendidikan profesi guru untuk menjadi guru profesional.

Dari banyaknya keterbatasan dalam peningkatan kualitas pendidikan di Indonesia, pekerja sosial memegang salah satu peranan penting dalam memastikan penyelenggaraan pemerataan pendidikan antara desa dan kota.

Salah satu peran dari profesi pekerja sosial adalah sebagai advokator, dimana pekerja sosial dapat mengetahui dan berusaha untuk menegakkan hak-hak anak khususnya hak untuk mendapatkan pendidikan, sehingga pekerja sosial bisa sebagai advokator bagi si anak untuk mendapatkan hak-hak yang seharusnya dia dapatkan. Peran pekerja sosial selanjutnya adalah sebagai pemercepat perubahan (enabler). Sebagai enabler, seorang pekerja sosial membantu individu-individu, kelompok-kelompok 
dan masyarakat dalam mengakses sistem sumber yang ada, mengidentifikasi masalah dan mengembangkan kapasitasnya agar dapat mengatasi masalah untuk pemenuhan kebutuhannya. Dalam hal ini pekerja sosial dapat membantu sekolah-sekolah yang membutuhkan bantuan dari Dinas Pendidikan baik untuk direnovasi sekolahnya ataupun penyediaan fasilitas sekolah.

Pekerja sosial juga bisa menjadi tenaga ahli (expert). Dalam kaitannya sebagai tenaga ahli, pekerja sosial dapat memberikan masukan, saran, dan dukungan informasi dalam berbagai area (individu-individu, kelompok-kelompok dan masyarakat). Dalam hal ini pekerja sosial dapat memberikan masukan dan saran untuk pemerintah dalam mengatasi kesenjangan pendidikan desa dan kota. Terakhir pekerja sosial dapat menjadi perencana sosial (social planner). Seorang perencana sosial mengumpulkan data mengenai masalah sosial yang dihadapi individu-individu, kelompokkelompok dan masyarakat, menganalisa dan menyajikan alternative tindakan yang rasional dalam mengakses sistem sumber yang ada untuk mengatasi masalah pemenuhan kebutuhan individuindividu, kelompok-kelompok dan masyarakat. Dalam hal ini pekerja sosial akan menganalisa permasalahan-permasalahan yang terjadi di sekolah yang terdapat di desa dan menyediakan solusi untuk pemerintah sehingga dapat mengatasi kesenjangan pendidikan desa dan kota.

\section{Daftar Rujukan}

Demanik, Juda. 2008. Pekerja Sosial Jilid 1. Jakarta: Direktorat Pembinaan Sekolah Menengah Kejuruan

Lie, Anita dkk. 2014. Menjadi Sekolah Terbaik; Praktik-Praktik Strategis dalam Pendidikan. Jakarta : Tanoto Foundation \& Raih Asa Sukses

Openshaw, Linda. 2008. Social Work in Schools. New York: The Guilford Press

Wibhawa, Budhi dkk. 2010. Dasar-Dasar Pekerjaan Sosial. Bandung: Widya Padjadjaran

Sumber Lainnya :

http://edukasi.kompas.com/read/2011/05/23/09200422/PHOTO.STORY.Perjuangan.untuk.Pendidik $\underline{\text { an }}$

http://infojambi.com/topik-utama/8306-potret-dunia-pendidikan-merangin-ada-sekolah-miripkandang-kambing.html

http://news.liputan6.com/read/2044900/potret-pendidikan-daerah-terpencil

http://news.liputan6.com/read/2109668/kemendikbud-bangga-atas-dedikasi-guru-sm3t-mendidikanak-negeri

http://www.padangmedia.com/1-Berita/89949-Jembatan-Putus--Anak-Sekolah-HarusMenyeberang-Sungai.html

http://wawachayoo.blogspot.com/

Undang - Undang Republik Indonesia No. 20 tahun 2003 tentang Sistem Pendidikan Nasional 